\title{
STUDI TENTANG FAKTOR-FAKTOR PENENTU BOND RATING PADA INDUSTRI PROPERTI, REAL ESTATE DAN PERUSAHAAN KONTRUKSI BANGUNAN YANG TERDAFTAR DI BEI PERIODE 2013-2017
}

\author{
Tatiek Ekawati Permana ${ }^{1}$ \\ Akademi Sekretari dan Manajemen Ariyanti \\ tatiek@ariyanti.ac.id \\ Ruli Mochammad Chaerudin ${ }^{2}$ \\ Universitas Bandung Raya \\ rulimoch@unbar.ac.id \\ Darul Wiyono ${ }^{3}$ \\ Akademi Sekretari dan Manajemen Ariyanti \\ darulwiyono@ariyanti.ac.id
}

\begin{abstract}
Abstrak - Peringkat obligasi berguna untuk investor dan penerbit, yang memberikan informasi tentang kemampuan perusahaan untuk membayar obligasi wajib seperti kupon dan nilai nominal. Ketika suatu pemeringkat menyatakan peringkat obligasi suatu obligasi mengalami kenaikan (upgrade) artinya pemeringkat melihat kinerja perusahaan baik. Sebaliknya jika peringkat obligasi mengalami penurunan (downgrade) memperlihatkan kinerja perusahaan tersebut mengalami penurunan. Tingkat rating semakin tinggi maka hal tersebut menunjukkan kemampuan penerbit obligasi untuk membayar utangnya semakin tinggi. Tujuan dari penelitian ini adalah untuk mengidentifikasi faktor-faktor penentu Bond Rating dengan menggunakan CEO power, Leverage, Size dan Profitabilitas sebagai penentu bond rating, dan menentukan mana dari variabel paling penting yang memiliki pengaruh kuat pada perusahaan. Sampel penelitian ini adalah perusahaan properti, real estate dan perusahaan konstruksi bangunan yang terdaftar di Bursa Efek Indonesia periode 2013-2017. Penelitian ini menggunakan metode analisis data panel untuk mengetahui faktor-faktor penentu Bond Rating (CEO power, Leverage, ukuran perusahaan dan profitabilitas) di Bursa Efek Indonesia dengan sampel sebanyak 9 perusahaan yang dipilih dengan menggunakan teknik purposive sampling periode 2013-2017. Hasil uji empiris menunjukkan bahwa leverage berpengaruh negatif terhadap peringkat oligasi (Bond Rating).
\end{abstract}

Kata kunci: peringkat obligasi, CEO power, leverage, ukuran perusahaan, profitabilitas

Abstract - Bond ratings are useful for investors and publishers, who provide information about the company's ability to pay mandatory bonds such as coupons and nominal value. When a rating states that the rating of bonds in a bond is upgraded, the rating considers the company's performance to be good. Conversely, if there is a decrease in bond rating (downgrade), it shows that the company's performance has decreased. The higher the rating level, the higher the ability of the bond issuer to pay its debt. The purpose of this 
research is to identify the determinants of Bond Rating by using CEO power, Leverage, Size and Profitability as a determinant of bond rating, and determine which of the most important variables that have a strong influence on the company. The sample of this research is property companies, real estate and building construction companies listed on the Indonesia Stock Exchange for the period 2013-2017. This study uses panel data analysis method to determine the determinants of Bond Rating (CEO power, Leverage, company size and profitability) on the Indonesia Stock Exchange with a sample of 9 companies selected using a purposive sampling technique for the period 2013-2017. The empirical test results show that leverage negatively affects the bond rating.

Keyword: Bond Rating, CEO power, leverage, size, profitability

\section{PENDAHULUAN}

Dana atau modal dibutuhkan perusahaan dalam menjalankan kegiatannya. Dana atau modal tersebut dapat diperoleh melalui pasar modal. Pasar modal merupakan pasar untuk berbagai instrumen keuangan atau sekuritas jangka panjang yang bisa diperjualbelikan, baik dalam bentuk utang maupun modal sendiri (Darmadji \& Fakhruddin, 2011).

Salah satu instrumen yang diperdagangkan di pasar modal adalah obligasi. Obligasi juga disebut sebagai fixed income atau instrumen dengan pendapatan tetap karena pendapatan yang didapat pemilik obligasi baik dalam bentuk kupon maupun pokok telah ditentukan waktu dan nilainya serta tidak terpengaruh oleh perubahan harga surat hutang tersebut. Peringkat obligasi sebagian besar ditentukan oleh rasio keuangan termasuk leverage, likuiditas, profitabilitas, cukupan utang dan size (Gentry et al., 1988 ; kim \& Gu, 2003).

Tata kelola perusahaan juga merupakan faktor penentu penting dari peringkat obligasi (Bhojraj dan Sengupta, 2003). Raharja dan Sari (2008) menyatakan bahwa peringkat obligasi penting karena peringkat tersebut memberikan pernyataan yang informatif sekaligus memberikan sinyal tentang profitabilitas kegagalan suatu hutang di perusahaan. Tingkat peringkat obligasi beragam dari satu Lembaga pemeringkat ke Lembaga pemeringkat lainnya Tandelilin (2010). Agen pemeringkat ini menilai dan mengevaluasi sekuritas hutang perusahaan yang di perdagangkan, terdapat tiga komponen utama yang digunakan oleh agen pemeringkat untuk menentukan peringkat (rating) obligasi, yaitu kemampuan perusahaan penerbit untuk memenuhi kewajiban finansialnya sesuai dengan yang di per janjikan, struktur dan berbagai ketentuan yang di atur dalam surat hutang, perlindungan yang diberikan maupun posisi klaim dari pemegang surat hutang tersebut bila terjadi pembubaran/likuidasi serta hukum lainnya yang mempengaruhi hal-hak kreditur.

Pada prinsipnya, peringkat obligasi semakin tinggi maka risiko yang dihadapi oleh investor semakin rendah mengingat semakin kecil kemungkinan obligasi mengalami kegagalan dalam membayar bunga dan pokok pinjaman Hadianto \& Wijaya, B. (2010). Adapun faktor-faktor yang mempengaruhi bond rating yang akan diteliti oleh penulis adalah CEO power, laverage, size, dan profitabilitas. Hasil penelitian pathan (2009) menyatakan 


\section{STUDI TENTANG FAKTOR-FAKTOR PENENTU BOND RATING PADA INDUSTRI \\ PROPERTI, REAL ESTATE DAN PERUSAHAAN KONTRUKSI BANGUNAN YANG TERDAFTAR DI BEI PERIODE 2013-2017}

bahwa CEO power yang kuat dapat disebabkan karena masa jabatan dari CEO yang sudah lama yang mengakibatkan pemegang obligasi mengantisipasi tindakannya Anderson dkk (2004).

Pada akhir-akhir ini muncul beberapa fenomena pada bisnis Property dan real estate dilingkungan global maupun regional yang menarik untuk diamati, antara lain: (1) Pasca krisis moneter, pertumbuhan industry property dan real estate di Indonesia menunjukkan peningkatan yang sangat tinggi. Peningkatan tersebut disebabkan oleh banyaknya pembangunan pusat-pusat perdagangan serta gedung-gedung perkantoran. (2) industri property dan real estate merupakan bidang bisnis yang mempunyai siklus yang cepat berubah presistensi dan kompleks. Gambaran fenomena tersebut tentunya dapat mempengaruhi tingkat retrun saham dalam perusahaan property dan real estate.

Fenomena di atas menjelaskan bahwa sektor bisnis property, real estate, dan konstruksi bangunan merupakan salah satu kegiatan bisnis yang sangat berkembang. Hal tersebut terbukti dengan adanya krisis yang terjadi di benua Eropa dan Amerika yang tidak mempunyai dampak dan tidak mempengaruhi perkembangan bisnis property, real estate, dan konstruksi bangunan di Indonesia. Krisis di Benua Eropa dan Benua Amerika memang mempunyai dampak yang sangat besar pada pasar global secara umum, namun, dilihat dari segi bisnis property, real estate, dan konstruksi bangunan, Indonesia memang tidak terlalu terkena imbasnya. Negara Indonesia masih menjadi negara tujuan yang ideal untuk melakukan investasi di sektor property, real estate, dan konstruksi bangunan terutama di tengah-tengah krisis ekonomi global yang saat ini terjadi.
Pembangunan di bidang bisnis property, real estate, dan konstruksi bangunan yang meningkat ini sebagai tanda bahwa mulai terdapat perbaikan perekonomian di Indonesia membaik ke arah masa depan lebih baik. Pertumbuhan perekonomian di Indonesia tumbuh sekitar $10 \%$ pertahun yang ditunjang oleh sektor property, real estate, dan konstruksi bangunan.

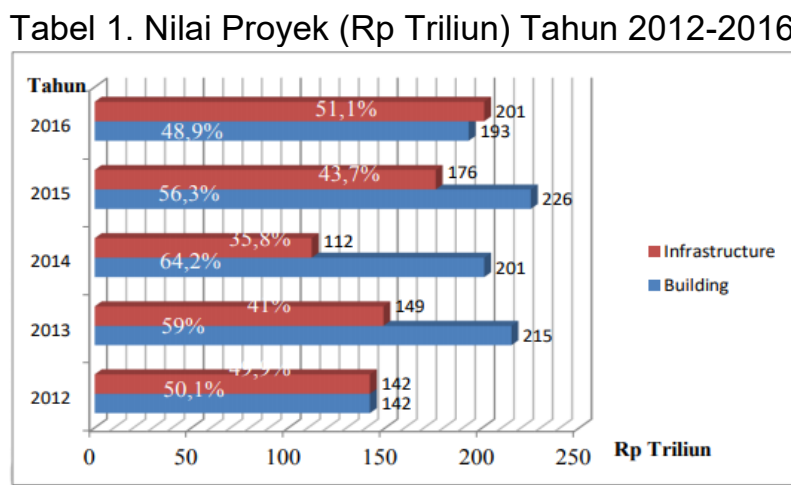

Sumber: Building and Contruction Interchange (BCl) Asia, diolah 2018

Tabel 1 di atas menggambarkan bahwa di periode 2012-2015, pembangunan proyek konstruksi didominasi oleh sektor property seperti perkantoran dan residensial. Bahkan di tahun 2014, pembangunan property di sektor konstruksi proporsinya mencapai 64,2\%. Di tahun 2016 akan lebih didominasi oleh sektor konstruksi untuk infrastruktur karena pemerintah akan banyak mengeksekusi pelaksanaan proyek-proyek infrastruktur terutama yang sudah masuk dalam Rencana Kerja Pemerintah (RKP) 2016.

\section{KAJIAN LITERATUR}

\section{CEO Power}

Dominasi CEO menunjukkan seberapa besar kekuatan pengambilan keputusan terkonsentrasi di tangan CEO. Ada empat sumber kekuatan CEO, yaitu: 
(1) kekuatan struktural, (2) kekuatan kepemilikan, (3) kekuatan ahli, dan (4) kekuatan prestise (Liu dan Jiraporn, 2010). Kekuatan struktural adalah yang paling sering dikutip dalam literatur dan didasarkan pada struktur organisasi formal dan otoritas Dalam penelitian ini berfokus pada kekuatan struktural, terutama kekuatan CEO di atas tim eksekutif puncak.

Dimensi utama dari karakteristik tim manajemen adalah distribusi bagaimana kekuatan dalam pengambilan keputusan. Apabila kegiatan pengambilan sebuah keputusan perusahaan lebih terkonsentrasi di tangan CEO, maka CEO akan memiliki lebih banyak kebijaksanaan dalam mempengaruhi keputusan, sehingga pendapatnya tercermin secara langsung dalam hasil perusahaan. Bebchuck dkk (2009) mengatakan bahwa dominasi CEO yang kuat dikaitkan dengan nilai perusahaan yang lebih rendah dan profitabilitas akuntansi yang buruk. Adam dkk (2005) mengatakan bahwa CEO yang kuat lebih cenderung tidak berkompromi dengan eksekutif lainnya dan variabilitas dalam kinerja perusahaan meningkat seiring dengan tingkat pengaruh CEO karena pengambilan keputusan lebih mungkin diambil saat CEO yang lebih dominan. Hasil penelitian Liu dan Jiraporn (2010) memperlihatkan bahwa perusahaan dimana kekuatan CEO lebih kuat memiliki peringkat kredit yang lebih rendah, dan dengan demikian mengalami biaya pembiayaan obligasi yang cenderung tinggi.

\section{Leverage}

Rasio leverage adalah rasio yang mengukur perbandingan dana yang disediakan oleh pemiliknya dengan dana yang dipinjam kreditur perusahaan tersebut. Macam-macam rasio rasio leverage, yaitu: (1) Debt to Asset Ratio
(DAR), (2) Debt to Equity Ratio (DER), (3) Long Term Debt to Equity Ratio (LTDER), dan (4) Times Interest Earned Ratio (TIE). Dari macam-macam rasio di atas, pada penelitian ini hanya menggunakan proksi Debt to Equty Ratio (DER). Rasio leverage merupakan rasio yang menunjukkan proporsi penggunaan utang untuk membiayai investasi terhadap modal yang dimiliki. Perusahaan dengan tingkat leverage yang rendah cenderung disukai para investor karena investor memiliki kepercayaan bahwa perusahaan akan mampu melunasi seluruh kewajibannya ketika utang tersebut telah jatuh tempo (Septyawanti, 2013). Tingginya rasio tersebut memperlihatkan bahwa sebagian besar asset didanai dengan utang dan ini menyebabkan perusahaan dihadapkan pada masalah default risk atau rating yang kurang baik dan sebaliknya. Rasio kebangkrutan yang besar mengakibatkan peringkat obligasi menjadi rendah. Sehingga semakin rendah leverage perusahaan, semakin baik peringkat yang di berikan kepada perusahaan (Subariah, 2017). Hasil penelitian sebelumnya yang dilakukan oleh Mahfudhoh, R. U. \& Cahyonowati, N., (2014) menunjukkan hasil bahwa rasio leverage mempunyai pengaruh signifikan terhadap bond rating.

\section{Size}

Ukuran perusahaan pada dasarnya adalah pengelompokan perusahaan ke dalam beberapa kelompok, yaitu perusahaan besar, sedang, dan kecil. Menurut Suwito dan Herawaty (2005) skala perusahaan merupakan ukuran yang dipakai untuk mencerminkan besar kecilnya perusahaan yang didasarkan kepada total asset perusahaan. Metode pengukuran dalam ukuran perusahaan dapat menggunakan berbagai cara, seperti total aktiva, log size, nilai pasar saham, dan lain-lain Saputri, D. P. O. S., \& 
Purbawangsa, I. B. A., (2016). Dalam penelitian ini, tolak ukur yang digunakan untuk mengukur ukuran perusahaan adalah menggunakan total aktiva atau total asset karena total asset perusahaan bernilai besar. Yuliani (2011) mengatakan bahwa semakin besar perusahaan dan semakin kenal oleh masyarakat maka semakin banyak informasi yang bisa diperoleh investor dan semakin kecil pula ketidakpastian yang dimiliki oleh investor. Alasan lainnya adalah dengan ukuran, perusahaan, investor dapat mengetahui kemampuan perusahaan dengan membayar bunga obligasi secara periodik dan melunasi pokok pinjaman yang dapat meningkatkan peringkat obligasi perusahaan. Menurut Meutia (2016:607) perusahaan besar mempunyai resiko relatif lebih kecil dibandingkan dengan perusahaan kecil. Semakin besar perusahaan, potensi mendiversifikasi risiko non-systematic semakin besar, sehingga membuat risiko obligasi perusahaan tersebut menurun. Hasi penelitian dari Surya dan Wuryani (2014) menunjukkan bahwa variable size mempunyai pengaruh terhadap bond rating.

\section{Profitabilitas}

Profitabilitas adalah rasio yang digunakan untuk mengukur kemampuan perusahaan untuk menghasilkan laba. Tujuan didirikannya perusahaan adalah memperoleh laba (profit), maka sangat wajar jika profitabilitas menjadi perhatian utama para investor dan analis. Biasanya penggunaan rasio profitabilitas disesuaikan dengan tujuan dan keutuhan perusahaan. Perusahaan dapat menggunakan rasio profitabilitas secara keseluruhan atau hanya sebagian saja dari jenis profitabilitas yang ada. Menurut Hery (2016:193) jenis-jenis rasio profitabilitas yang lazim digunakan dalam praktik untuk mengur ukuran perusahaan dalam menghasilkan laba Return on Assets, Return on Equity, Gross Profit Margin, Operating Profit Margin, dan Net Profit Marfin. Dalam penelitian ini tolak ukur yang digunakan untuk mengukur kemampuan perusahaan untuk menghasilkan laba dengan menggunakan Return on Assets (ROA). Dalam hal tersebut Profitabilitas dapat mengetahui efektivitas perusahaan dalam mengelola sumber-sumber yang dimilikinya. Semakin tinggi rasio profitabilitas maka semakin tinggi pula peringkat perusahaan Syawal, T. M., \& Fachrizal (2016). Manurung (2009) mengemukakan bahwa ROA mempunyai pengaruh signifikan terhadap peringkat obligasi.

\section{Hipotesis Development}

Penelitian ini akan meneliti hubungan antara variable CEO Power, Laverage, Size, dan Probabilitas yang dapat mempengaruhi bond rating dari sebuah perusahaan yang tercatat di Bursa Efek Indonesia sektor property, real estate dan building construction. Dari landasan teori, kerangka pemikiran, dan penelitian terdahulu maka hipotesis yang diajukan pada penelitian ini adalah sebagai berikut:

1. CEO Power berpengaruh positif terhadap Bond Rating di Industri Properti, Real Estate dan Perusahaan Konstruksi Bangunan yang Terdaftar di BEI Periode 2013-2017.

2. Leverage berpengaruh positif terhadap Bond Rating di Industri Properti, Real Estate dan Perusahaan Konstruksi Bangunan yang Terdaftar di BEI Periode 2013-2017.

3. Ukuran Perusahaan (Firm Size) berpengaruh positif terhadap Bond Rating di Industri Properti, Real Estate dan Perusahaan Konstruksi Bangunan 
yang Terdaftar di BEI Periode 20132017.

4. Profitabilitas berpengaruh positif terhadap Bond Rating di Industri Properti, Real Estate dan Perusahaan Konstruksi Bangunan yang Terdaftar di BEI Periode 2013-2017.

\section{METODE PENELITIAN}

Pada penelitian ini objek yang akan diteliti adalah CEO power diukur dengan menggunakan CEO pay Slice atau gaji, Leverage menggunakan proksi Debt to Equity Ratio, size dengan proksi total asset, profitabilitas dengan proksi Return on Asset yang akan dianalisis pengaruhnya terhadap bond rating pada perusahaan sektor property, real estate and building construction yang terdaftar di bursa efek Indonesia pada periode 2013 2017. Populasi dalam penelitian ini adalah perusahaan-perusahaan sector property, real estate and building construction yang terdaftar di Bursa Efek Indonesia periode 2013-2017 yang berjumlah Sembilan (9) perusahaan. Teknik pengambilan sampel dilakukan secara purposive sampling agar diperoleh sampel yang sesuai dengan kriteria yang ditentukan. Data yang digunakan dalam penelitian ini adalah data sekunder. Data sekunder adalah data yang dipublikasikan atau digunakan oleh organisasi lain, bukan oleh pengguna. Data dikumpulkan dari situs web resmi Bursa Efek Indonesia (www.idx.co.id) dan laporan tahunan perusahaan. Untuk informasi tambahan, peneliti juga menggunakan informasi yang sudah ada, seperti artikel, jurnal, buku teks, dan lain lain. Penelitian ini menggunakan kombinasi data deret waktu dan data penampang, yang dikenal sebagai pooling data/data panel. Data panel memberikan lebih banyak data informatif, lebih banyak variabilitas, lebih sedikit ko-linearitas antar variabel, lebih banyak derajat kebebasan, dan lebih banyak efisiensi (Zhao, 2013). Menurut Sugiyono (2014:38) variabel penelitian merupakan segala sesuatu yang berbentuk apa saja yang ditetapkan oleh peneliti untuk dipelajari sehingga diperoleh informasi tentang hal tersebut yang kemudian ditarik kesimpulan. Pada penelitian ini terdapat lima variabel yang terdiri dari empat variable independent (bebas) dan satu variabel dependen (terikat). Penjelasan dari variabel-variabel yang terdapat dalam penelitian ini adalah sebagai berikut.

\section{Variable dependent atau terikat (Y).}

Variabel dependen adalah tipe variabel yang dijelaskan atau dipengaruhi oleh variable independent. Pada penelitian ini variabel dependennya adalah bond rating. Variabel ini dilihat berdasarkan peringkat yang dikeluarkan oleh pefindo yang secara umum sebagai menjadi dua bagian yaitu investment grade (AAA, AA, $\mathrm{A}, \mathrm{BBB}$ ) dan non investment (BB, B, CCC, $D D)$. Variabel ini mengukur dengan skala.

\section{Variable independent atau variable bebas $(X)$}

Variabel independen adalah variabel yang tidak dapat dipengaruhi oleh variabel lainnya dan biasanya ditandai dengan huruf $X$ untuk memudahkan peneliti dan mengidentifikasi. variabel independen pada penelitian ini sebagai berikut:

\section{CEO POWER}

Menurut Liu dan Jirapora (2010) bahwa CEO power yang lebih kuat dikaitkan dengan biaya pembiayaan obligasi yang lebih tinggi. Perusahaan dimana CEO power yang lebih kuat memiliki peringkat kredit yang lebih rendah dan dengan demikian mengalami pembiayaan obligasi yang lebih tinggi. 
Menurut Bebchuk dkk (2009b) berpendapat bahwa CEO's pay slice (CPS) salah satu cara untuk melihat kemampuan, kontribusi, atau kekuasaan pada CEO. CPS dapat didefinisikan sebagai total kompensasi CEO dari gabungan total kompensasi yang termasuk gaji, bonus, pembayaran lainnya, pembayaran insentif jangka Panjang, nilai total saham, nilai opsi saham, dan kompensasi lainnya.

\section{LEVERAGE}

Tingginya rasio ini mengandung arti bahwa sebagian besar asset didanai dengan hutang dan ini menyebabkan perusahaan pada masalah default risk atau peringkat obligasi yang kurang baik. Semakin besar rasio ini maka semakin besar risiko kegagalan perusahaan dan peringkat obligasi semakin turun, dan sebaliknya Surya dan Wuryani (2014). Pada penelitian ini, Rasio Leverage di proyeksikan dengan menggunakan debt to equity ratio, dengan rumus sebagai berikut:

$$
\text { Debt to Equity Ratio }=\frac{\text { Total Liabilitas }}{\text { Total Ekuitas }}
$$

\section{SIZE}

Brigham dan Jouston (2009:117) mendefinisikan ukuran perusahaan (size) bagi rata-rata total penjualan bersih untuk tahun yang bersangkutan sampai beberapa tahun, ukuran perusahaan juga merupakan karakteristik suatu perusahaan dalam hubungannya dengan struktur perusahaan. Ukuran perusahaan dapat di hitung dengan total aset, penjualan maupun ekuitas yang dimiliki oleh perusahaan. Pada penelitian ini menggunakan proksi total aset untuk menghitung size.

\section{PROFITABILITAS}

Mengukur kemampuan perusahaan menghasilkan laba dalam hubungannya dengan tingkat penjualan, aset, maupun modal saham sendiri Maharti (2011). Pada penelitian ini menggunakan proksi Return on Asset (ROA), dimana semakin tinggi ROA berarti semakin mampu mendayagunakan aset dengan baik untuk memperoleh keuntungan. Rumus dari ROA adalah sebagai berikut adalah:

$$
\text { Return On Asset }=\frac{\text { Laba Bersih }}{\text { Total Asset }}
$$

cara untuk menguji hipotesis yang diajukan dalam penelitian ini menggunakan model regresi data panel seperti yang digunakan oleh Kajola, Desu, \& Agbanike (2015). Langkah utama dalam melakukan model regresi data panel telah melakukan beberapa tes asumsi klasik yang terdiri dari normalitas, multikolinieritas, autokorelasi, dan uji heteroskedastisitas. Tujuan dari uji asumsi klasik adalah untuk memastikan bahwa model persamaan regresi memiliki akurasi dalam estimasi, tidak bias, dan konsisten. Uji ketepatan model regresi dalam memprediksi nilai variabel dependen ditentukan oleh goodness-of-fit. Dalam mengukur goodness-of-fit, model regresi data panel dapat dianalisis melalui uji-F. Ftest dikenal sebagai Anova test digunakan untuk menemukan hubungan antara variabel independen dan variabel dependen atau untuk menguji apakah model yang digunakan adalah fix atau tidak (Lind, Marchal, \& Wathen, 2012). Selanjutnya, uji R2 yang merupakan uji koefisien determinasi untuk mengukur kemampuan variabel independen yang digunakan untuk mendefinisikan 
perubahan pada variabel dependen. Tes terakhir adalah uji-t atau uji hipotesis, digunakan untuk menganalisis dampak dari masing-masing variabel independen secara individual terhadap variabel dependen atau untuk menjawab seluruh hipotesis yang diajukan dalam penelitian ini.

\section{HASIL PENELITIAN}

Hasil uji normalitas menggunakan uji JarqueBera menunjukkan bahwa nilai probabilitas Jarque-Bera adalah $0,062809>D(D=0,05)$, dapat dikatakan bahwa data terdistribusi normal. Karena perbedaan sangat tipis masih dapat digunakan untuk analisis lebih lanjut merujuk pada teorema limit pusat oleh McClave et al. (2013). Selanjutnya, uji multikolinieritas menggunakan matriks korelasi untuk setiap variabel independen yang dihasilkan melalui pengolahan data menunjukkan bahwa koefisien korelasi di bawah 0,8 , yang berarti tidak ada masalah dengan multikolinieritas dalam model penelitian. Hasil uji autokorelasi menggunakan uji Durbin-Watson menunjukkan bahwa nilai yang dihitung adalah 0,9718 dan tabel Durbin-Watson adalah $\mathrm{dL}=0,29571$ dan $\mathrm{dU}=2,58810$, tidak menunjukkan hasil tertentu karena nilai Durbin-Watson yang dihitung antara 4$\mathrm{dL}$ dan 4-DU. Namun, dapat disimpulkan bahwa tidak ada autokorelasi karena Durbin-Watson yang dihitung mendekati 2. Hasil heteroskedastisitas menggunakan uji $\mathrm{ARCH}$ menghasilkan $\mathrm{p}$ value-obs * -square $0,7288>0,05$, yang berarti tidak ada heteroskedastisitas di antara residual dalam model regresi atau varians residu tetap sama di pengamatan yang berbeda atau nilai yang berbeda dari variabel independen. Hasil redundant fixed effect atau likelihood ratio untuk model ini memiliki nilai probabilitas $\mathrm{F}$ sebesar 0.0000 lebih kecil dari Alpha 0.05, sehingga model yang sesuai dari hasil ini adalah fixed effect. di lihat dari hasil uji hausman juga menunjukkan nilai 0.0000 (tidak signifikansi < 0.05), sehingga dapat diartikan bahwa model fixed effect lebih baik dari model random effect. Selanjutnya, Hasil output dari Langrange Multiplier (LM) menunjukkan nilai Probabilitas BreushPagan (BP) sebesar 0.0000, Hipotesisnya adalah jika Probabilitas Breush-Pagan (BP) lebih kecil dari Alpha $(0.0000<0.05)$ maka, yang jadi model yang tepat pada hasil di atas adalah Random effect. Hasil regresi data panel dengan menggunakan model efek tetap menunjukkan koefisien variabel independen, t-statistik, probabilitas, koefisien determinasi, dan uji F seperti yang ditunjukan pada tabel 2 .

Tabel 2. Hasil Regresi Data Panel

\begin{tabular}{llll}
\hline \hline & & & \\
Variable & Coefficient & t-Statistic & Prob. \\
\hline \hline CEO & 0.028734 & 1.464227 & 0.1509 \\
DER & -0.062210 & -1.918682 & 0.0622 \\
LNTA & 0.210381 & 3.371476 & 0.0017 \\
ROA & 2.334161 & 2.444827 & 0.0190 \\
C & -3.422481 & -1.464430 & 0.1509 \\
\hline \hline & & & \\
R-squared & & \\
F-statistic & 0.404981 & \\
Prob(F-statistic) & 6.806182 & \\
\end{tabular}

Hasil analisis regresi menunjukkan bahwa koefisien variasi (b) yang menjelaskan arah variabilitas negatif untuk DER, yang berarti jika DER dalam satu unit, maka DPR akan mengurangi jumlah koefisien variasi (b). Sedangkan ukuran positif, artinya, jika ukuran bertambah dalam satu unit, maka DPR akan bertambah besar koefisien variasi (b) ukuran. Hasil uji F menunjukkan bahwa variabel independen yang digunakan dalam penelitian ini mampu mendefinisikan variabel dependen dengan cara yang baik atau model regresi diperbaiki. Model yang 
dikembangkan untuk kebijakan dividen cukup baik, karena koefisien determinasi $\left(R^{2}\right)$ seperti yang ditunjukkan pada tabel 2 adalah 0,404981 . Hal ini berarti bahwa variasi dalam kebijakan dividen dalam sector property, real estate and building construction yang terdaftar di Bursa Efek Indonesia dapat dijelaskan oleh variasi dalam CEO, DER, LNTA, dan ROA yang berkontribusi sebesar 40,50 persen, sedangkan sisanya sebesar 59,50 persen dijelaskan oleh variasi variabel lain yang tidak masuk dalam penelitian. Hasil penelitian ini mempertegas hasil penelitianpenelitian sebelumnya bahwa faktor-faktor yang berpengaruh terhadap peringkat obligasi adalah ukuran perusahaan (firm size), profitabilitas (profitability), leverage, produktivitas (productivity), pertumbuhan perusahaan (growth), jaminan (secure), dan umur obligasi (maturity) (Mahfudhoh, R. U., \& Cahyonowati, N., 2014:12).

Hasil pengujian

hipotesis

menunjukkan bahwa CEO power (CEO) dan profitabilitas berpengaruh positif terhadap bond rating, oleh karena itu rumusan hipotesis penelitian ditolak. Leverage berpengaruh negatif terhadap kebijakan dividen perusahaan, sehingga rumusan hipotesis penelitian diterima. Sementara itu, Ukuran perusahaan/Size (LNTA) dan profitabilitas (ROA) tidak berpengaruh terhadap Bond Rating di sector property, real estate and building construction yang terdaftar di Bursa Efek Indonesia. Oleh karena itu rumusan hipotesis penelitian ditolak.

\section{PEMBAHASAN}

CEO power memiliki insentif untuk mengurangi risiko perusahaan bagi pemegang saham. Sebagai orang yang dominan di dalam perusahaan, CEO yang kuat memiliki lebih banyak kebijaksanaan untuk mempengaruhi keputusan dan karenanya lebih cenderung mengurangi risiko proyek yang diimplementasikan Liu dan Jirapora (2010). Hasil penelitian menunjukkan bahwa naik dan turunnya CEO power yang diukur dengan gaji tidak memberikan pengaruh terhadap naik dan turunnya Bomd Rating pada perusahaan sector properti, real estate dan perusahaan konstruksi bangunan yang terdaftar di Bursa Efek Indonesia 2013-2017.

Leverage mengukur bagaimana perusahaan bergantung pada dana eksternal (tingkat utang) untuk membiayai investasi mereka. Karenanya leverage memiliki hubungan terbalik dengan bond rating. Hasil penelitian Leverage yang di dapatkan dengan proksi Debt to Equity bernilai negative berpengaruh negatif terhadap Bond Rating. Temuan ini sejalan dengan penelitian yang dilakukan oleh Vo \& Nguyen (2014) dan Ahmad \& Wardani (2015), mereka mengatakan ada hubungan negatif antara leverage keuangan dan kebijakan dividen. Temuan ini menarik, karena hasilnya menunjukkan bahwa ketika tingkat utang perusahaan meningkat, maka pembayaran dividen akan berkurang. Leverage tinggi menunjukkan tingkat risiko keuangan dan syarat pembayaran utang yang tinggi, harus dikaitkan dengan penurunan pembayaran dividen. Perusahaan dengan pemikiran leverage tinggi untuk mengurangi kebijakan dividen dengan tujuan membatasi risiko default.

Skala perusahaan merupakan ukuran yang di pakai untuk mencerminkan besar kecilnya perusahaan yang didasarkan kepada total asset perusahaan. Dalam penelitian ini size berpengaruh positif atau dapat diartikan bahwa size memiliki pengaruh terhadap bond rating. Hasil penelitian ini sejalan dengan teori yang mengatakan bahwa perusahaan besar memiliki peringkat obligasi yang lebih baik dari pada perusahaan kecil karena 
mempunyai kemampuan dalam menjaminkan aktivanya sehingga berdampak pada rendahnya risiko yang dihadapi Tandellin (2010:247). Semakin besar total asset yang dimiliki perusahaan maka perusahaan mempunyai kemampuan dalam melunasi kewajiban dimasa depan. Mengingat jumlah asset yang besar dapat dijadikan sebagai jaminan penerbitan obligasi Surya dan Wuryani (2014).

Profitabilitas

perusahaan menentukan keputusan perusahaan untuk Bond Rating. Pada Penelitian ini Profitabilitas berpengaruh positif terhadap Bond Rating. Hasil dari penelitian ini tidak berpengaruh terhadap bond rating. Hasil penelitian ini bertentangan dengan teori yang mengatakan bahwa semakin tinggi tingkat profitabilitas perusahaan maka semakin rendah risiko ketidakmampuan membayar kewajiban atau default dan semakin baik peringkat yang diberikan terhadap perusahaan tersebut Burton et al (2003). Maka dari itu penelitian ini sejalan dengan penelitian Kustiyaningrum dkk (2016), Pabintan (2015), dan Subariah (2017) yang menyatakan bahwa profitabilitas tidak berpengaruh terhadap bond rating. Mereka berpendapat bahwa investor tidak memperhitungkan tingkat profitabilitas perusahaan melainkan mempertimbangkan ketersediaan jaminan jika suatu saat perusahaan mengalami gagal bayar (default risk).

\section{PENUTUP}

Kesimpulan Tujuan dari penelitian ini adalah untuk mengidentifikasi faktor-faktor penentu Bond Rating dengan menggunakan CEO power, Leverage, Size dan Profitabilitas sebagai penentu bond rating, dan menentukan mana dari variabel paling penting yang memiliki pengaruh kuat pada perusahaan. Hasil regresi data panel menunjukkan hubungan negatif antara leverage dengan bond rating. Sementara itu, CEO power, Size (ukuran perusahaan), dan profitabilitas tampaknya tidak berpengaruh signifikan terhadap peringkat obligasi (bond rating) di industry perusahaan properti, real estate dan perusahaan konstruksi bangunan yang terdaftar di Bursa Efek Indonesia. Hubungan antara CEO power, profitabilitas berada di luar harapan, karena bertentangan dengan teori dan sejumlah penelitian sebelumnya. Sedangkan leverage memiliki hubungan seperti yang diharapkan. Hasil kontras juga terlihat dalam hubungan antara bond rating dengan ukuran perusahaan (size). Beda hasil dengan sejumlah teori dan peneliti sebelumnya yang menunjukkan seluruh variabel memiliki hubungan dengan kebijakan dividen. Hasil penelitian ini dapat menjadi informasi oleh investor bahwa kebijakan dividen di industri perusahaan properti, real estate dan perusahaan konstruksi bangunan yang terdaftar di Bursa Efek Indonesia untuk periode 20132017 dipengaruhi oleh Bond Rating.

\section{SARAN}

Bagi Investor yang hendak berinvestasi obligasi pada perusahaan sektor property, real estate and building construcion disarankan agar tidak berinvestasi pada perusahaan yang sudah memiliki utang yang tinggi karena akan berisiko gagal bayar yang tinggi pula.

\section{DAFTAR PUSTAKA}

Adams, R. Almeida, H. Ferreira, D. (2005). Powerful Ceos And Their Impact On corporate Perfomance. Review of Financial Studies, Vol. 8, Issue 4, 1403-1432 
Anderson, R.C. Mansi, SA. Reeb, D.M. (2004). Board Characteristics, Accounting Reporting Integrity, And The Cosdt of Debt. Journal of Accounting and Economics, Vol.3, Issues 3, September 2004, Pages 315342

BCI Asia Indonesia's Infrastructure: Successes and Hurdles. (2017). Developing the Country Together Industry Review \& Forecast Project \& Interior: Hotel, Resort, Offices, Residential \& Restaurant. Issue 6. Jakarta: PT. Gramedia Printing.

Bebchuk, L. Cremers, M. Peyer, U. (2007). Pay Distribution In The Top Executive Team. Yale School of Management, Harvard Law School and NBER.

Brigham, E.F. Houston, J.F. (2009). DasarDasar Manajemen Keuangan, Buku Satu, Edisi Kesepuluh, Alih Bahasa Ali Akbar Yulianto. Jakata: Salemba Empat.

Darmadji, T. Fakhruddin, M.H. (2011). Pasar Modal di Indonesia Pendekatan dan Tanya Jawab. Edisi ketiga. Jakarta: salemba Empat.

Gusni Tanjung. (2017). The Determinants of Dividend Policy: A Study of Financial Industry in Indonesia. Jurnal Keuangan dan Perbankan Universitas Widyatama.

Hadianto, B. Wijaya, M.S.V. (2010). Prediksi Kebijakan Utang, Profitabilitas, Likiuiditas, Ukuran, dan Status Perusahaan Terhadap Kemungkinan Penentuan Peringkat Obligasi. Jurnal Manajemen Teori dan Terapan, Tahun 3, No.3.
Hery. (2017). Analisis Laporan Keuangan: Integrated and Comprehensive Edittion. Cetakan ke-2. Jakarta: PT. Grasindo.

Liu, Y. Jiraporn, P. (2010). The Effect of CEO Power On Bond Ratings And Yields. Journal of Empirical Finance 17, 744762.

Maharti, E.D. (2011). Analisis Faktor-Faktor yang Mempengaruhi Peringkat Obligasi. Jurnal Universitas Diponegoro

Mahfudhoh, R. U., \& Cahyonowati, N. (2014). Analisis Faktor-Faktor Yang Mempengaruhi Peringkat Obligasi. Diponegoro Journal of Accounting, 1(1), 1-13.

Manurung, A.H. Silitonga, D. Tobing, W.R.L. (2018) Hubungan Rasio-Rasio Keuangan Dengan Rating Obligasi. Jurnal Keuangan ABFI Institut Perbanas Jakarta

McClave, J. T., \& Sincich, T. L. (2013). Statistics. 12th Edition. Boston: Pearson

Meutia, T. (2016). Pengaruh Growth Opportunity, Profitabilitas, dan Ukuran Perusahaan terhadap Struktur Modal pada Perusahaan Properti di Bursa Efek Indonesia. Jurnal Manajemen dan Keuangan Universitas Samudra. 5(2). 603-614.

Pathan, C. (2009). Strong Boards, Ceo Power and Bank Risk-Taking. Journal of Banking and Finance, Vol.33, Issue 7, July 2009, Pages 1340-1350

Saputri, D. P. O. S., \& Purbawangsa, I. B. A., (2016). Pengaruh Leverage, Profitabilitas, Pertumbuhan 
Perusahaan, dan Jaminan Terhadap Peringkat Obligasi Sektor Jasa di Bursa Efek Indonesia. E-Jurnal Manajemen Unud, 5(6), 3706-3705.

Septyawanti, H.I. (2013). Faktor-Faktor yang Mempengaruhi Prediksi Obligasi Perusahaan. Accounting Analysis Journal Universitas Negeri Semarang.

Subariah, (2017). Analisis Faktor-Faktor yang Mempengaruhi Prediksi Peringkat Obligasi Pada Perusahaan Keuangan yang terdaftar di Bursa Efek Indonesia. Jurnal Akuntansi Fakultas Ekonomi Universitas Maratime Raja Ali Haji.

Sugiyono. (2014), Metode Penelitian Kuantitatif Kualitatif Dan RED. Bandung: Alfabeta.

Surya, E.l. Wuryani, E. (2014). Pengaruh Ukuran Perusaan (firm Size), Profitabilitas, Likuiditas, Priduktivitas dan Laverage Terhadap Peringkat Obligasi, Jurnal Fakultas Akuntansi Universitas Negeri Surabaya.

Suwito, E. Herawati, A. (2005). Analisis Pengaruh Karakteristik Perusahaan Terhadap Tindakan Peralatan Laba yang Dilakukan Oleh Perusahaan yang Terdaftar Di Bursa Efek Jakarta. Simposium nasional akuntansi VIII Solo. 15-16 september.

Syawal, T. M., \& Fachrizal. (2016). Pengaruh Profitabilitas, Interest Coverage Ratio, Retained Earning, dan Pertumbuhan Perusahaan Terhadap Peringkat Obligasi pada Perusahaan Non Keuangan Yang Terdaftar Di Bursa Efek Indonesia Tahun 2012-2014. Jurnal Ilmiah
Mahasiswa Ekonomi Akuntansi (JIMEKA) FEB Unsyiah, 1(2), 237-251.

Tendelilin, E. (2001). Analisa investasi dan manajemen portofolio. Yogyakarta: BPFE UGM.

Vo, D. H., \& Nguyen, V. T. -Y. (2014). Managerial ownership, leverage, and dividend policies: Empirical evidence from Vietnam's listed firms. International Journal of Economics and Finance, 6(5), 274-284. 